\title{
A new, reliable, and high-throughput strategy to screen bacteria for antagonistic activity against Staphylococcus aureus
}

Soyoun Park', Adam Classen', Hanny Maeva Gohou', Roberto Maldonado ${ }^{1}$, Emily Kretschmann ${ }^{1}$, Chloe Duvernay ${ }^{1}$, Geun-Joong Kim ${ }^{2}$ and Jennifer Ronholm ${ }^{1,3^{*}}$

\begin{abstract}
Background: Antibiotic-resistant Staphylococcus aureus clones have emerged globally over the last few decades. Probiotics have been actively studied as an alternative to antibiotics to prevent and treat S. aureus infections, but identifying new probiotic bacteria, that have antagonistic activity against $S$. aureus, is difficult since traditional screening strategies are time-consuming and expensive. Here, we describe a new plasmid-based method which uses highly stable plasmids to screen bacteria with antagonistic activity against $\mathrm{S}$. aureus.

Results: We have created two recombinant plasmids (pQS1 and pQS3) which carry either gfp $p_{b k}$ or $m$ Cherry under the control of a S. aureus quorum-sensing (QS) promoter (agrP3). Using this recombinant plasmid pair, we tested 81 bacteria isolated from Holstein dairy milk to identify bacteria that had growth-inhibiting activity against $\mathrm{S}$. aureus and suggest potential explanations for the growth inhibition. The stability test illustrated that PQS1 and pQS3 remained highly stable for at least $24 \mathrm{~h}$ in batch culture conditions without selection pressure from antibiotics. This allowed coculturing of S. aureus with other bacteria. Using the newly developed pQS plasmids, we found commensal bacteria, isolated from raw bovine milk, which had growth-inhibiting activity $(n=13)$ and quorum-quenching $(\mathrm{QQ})$ activity $(n=$ 13) towards both S. aureus Sa25 (CC97) and Sa27 (CC151). The PQS-based method is efficient and effective for simultaneously screening growth-inhibiting and QQ bacteria against $S$. aureus on agar media.

Conclusions: It was shown that growth-inhibiting and QQ activity toward pQS plasmid transformants of S. aureus can be simultaneously monitored by observing the zone of growth inhibition and reporter protein inhibition on agar plates. Newly identified antagonistic bacteria and their functional biomolecules are promising candidates for future development of probiotic drugs and prophylactics/therapeutics for bacterial infections including S. aureus. Furthermore, this new approach can be a useful method to find bacteria that can be used to prevent and treat $\mathrm{S}$. aureus infections in both humans and animals.
\end{abstract}

Keywords: S. aureus, Quorum-sensing, Quorum-quenching, pKK30

\footnotetext{
* Correspondence: Jennifer.Ronholm@mcgill.ca

'Department of Food Science and Agricultural Chemistry, Faculty of

Agricultural and Environmental Sciences, McGill University, Macdonald

Campus, 21,111 Lakeshore Ste Anne de Bellevue, QC H9X 3V9 Montreal,

Canada

${ }^{3}$ Department of Animal Science, Faculty of Agricultural and Environmental

Sciences, McGill University, Macdonald Campus, 21,111 Lakeshore,

Ste-Anne-de-Bellevue, QC H9X 3V9, Canada

Full list of author information is available at the end of the article
}

(C) The Author(s). 2021 Open Access This article is licensed under a Creative Commons Attribution 4.0 International License, which permits use, sharing, adaptation, distribution and reproduction in any medium or format, as long as you give appropriate credit to the original author(s) and the source, provide a link to the Creative Commons licence, and indicate if changes were made. The images or other third party material in this article are included in the article's Creative Commons licence, unless indicated otherwise in a credit line to the material. If material is not included in the article's Creative Commons licence and your intended use is not permitted by statutory regulation or exceeds the permitted use, you will need to obtain permission directly from the copyright holder. To view a copy of this licence, visit http://creativecommons.org/licenses/by/4.0/. The Creative Commons Public Domain Dedication waiver (http://creativecommons.org/publicdomain/zero/1.0/) applies to the data made available in this article, unless otherwise stated in a credit line to the data. 


\section{Background}

Staphylococcus aureus is a common bacterial pathogen that has potential to cause serious infections in humans and several species of wild and agricultural animals [1]. $S$. aureus isolates have a remarkable level of variation in terms of metabolic potential, virulence, and antibiotic resistance (ABR) [2]. Unfortunately, several multi-drug resistant $S$. aureus lineages have emerged in hospitals, community settings, and livestock operations globally over the last few decades [1]. Alternatives to antibiotics for the treatment and prevention of $S$. aureus infections in both human and veterinary medicine are needed. Probiotics have been suggested as a possible alternative to antibiotics, and specific probiotics that are able to prevent $S$. aureus colonization and growth, such as lactic acid bacteria, are of great interest [3, 4]. For instance, probiotic Bacillus can halt S. aureus colonization and eliminate $S$. aureus cells through the inhibition of its signalling system [5-7].

Quorum-quenching (QQ) is a means of disrupting $S$. aureus quorum-sensing (QS) ability which has shown the potential to reduce $S$. aureus pathogenicity $[8,9]$. In $S$. aureus several genes, including virulence factors, are under the control of the accessory gene regulator (agr) QS system. There are four different $S$. aureus agr groups, and each agr group is associated with different $S$. aureus phylogenetic lineages. Members of the same agr group produce the same autoinducing peptides (AIP) and specific receptors for the designated AIP [10]. Subtypes of AIPs have been shown to be inhibitory towards heterologous agr systems via interfering in the interactions between cognate AIP and their receptors [10]. Nonpathogenic bacteria with $S$. aureus QQ activity have the potential to be further developed as probiotics. S. epidermidis and $S$. caprae, for example, produce heterologous AIPs and attenuate $S$. aureus virulence by interfering its agr-mediated QS [8, 11]. Other bacteria capable of perturbing $S$. aureus membrane and inhibiting RNA III have a potent to suppress the virulence phenotype of $S$. aureus [12, 13]. Synthetic and natural quorumquenchers have been studied in multiple papers and appeared to be effective in drug development $[14,15]$.

In several instances probiotics that have successfully antagonized and reduced the growth of human bacterial pathogens have been originally isolated from the microbiome of healthy individuals [16, 17]. However, traditional methods to identify isolates with potential antimicrobial or QQ activity are time-consuming and laborious, and separate experimental pipelines are required to detect growth inhibition and QQ ability. In antimicrobial activity tests, co-culturing $S$. aureus with other bacteria in liquid media requires a prolonged enumeration step such as plate counting on selective agar media [18]. More sophisticated techniques are available to test QQ such as beta-galactosidase assay [19], fluorescent reporter assay [8], and mRNA quantification [20]. However, few genetically engineered S. aureus strains are available, and this limits options for rapidly testing potential antagonists against a broad range of $S$. aureus lineages.

Manipulation of bacterial plasmids is easier and safer than manipulation of chromosomal DNA. Plasmid-based genetic tools are commonly used to introduce reporter genes to bacterial cells, but a plasmid-based system is not always the best option in co-culture conditions due to the requirement to include antibiotics in the media to retain plasmids. This limitation results from two elements: the potential metabolic changes in the presence of antibiotics, and the susceptibility of putative antagonistic bacteria to the antibiotics used. However, Krute et al. generated a highly stable plasmid in the absence of antibiotics (pKK30), and Rodriguez et al. modified this plasmid by inserting reporter genes to visualize $S$. aureus cells in vitro and in vivo [21, 22]. These studies demonstrated that the stability of pKK30 and its recombinant plasmids was remarkably well maintained for more than 100 generations.

In this study, our aim was to develop a new highthroughput plasmid-based strategy to screen bacterial isolates for antagonistic activity against $S$. aureus while minimizing costs and labour. We evaluated the stability and performance of the pQS series of plasmids and then applied this new system to screen a bacterial culture collection of bovine mammary commensals to identify isolates those with antagonistic activity against two lineages of $S$. aureus which commonly cause mastitis in dairy cattle (CC151 and CC97) [1]. Using our new system, we were able to simultaneously identify which isolates were able to inhibit $S$. aureus growth as well as determine which were accomplishing growth inhibition through QQ. Our results highlight the benefits of this novel screening approach.

\section{Results}

The recombinant plasmids pQS1 and pQS3 which encode the fluorescent genes $g f p_{b k}$ and $m$ Cherry, respectively, under $S$. aureus QS promoter (agrP3) were generated using a variety of restriction enzymes and T4 DNA ligase (Fig. 1A). The sequences of pQS1 (accession number MW344079) and pQS3 (accession number MW344080) have been deposited in GenBank at the NCBI (GenBank, https://www.ncbi.nlm.nih.gov/ genbank/). S. aureus harbouring both pQS1 and pQS3 expressed GFP and mCherry, yet the expression of the reporter proteins was not detected in S. aureus RN4220 (agr defective strain) (Additional file 1: Figure S1). We then applied the pQS series to establish a new screening strategy to monitor $S$. aureus QS in agar plates. The 


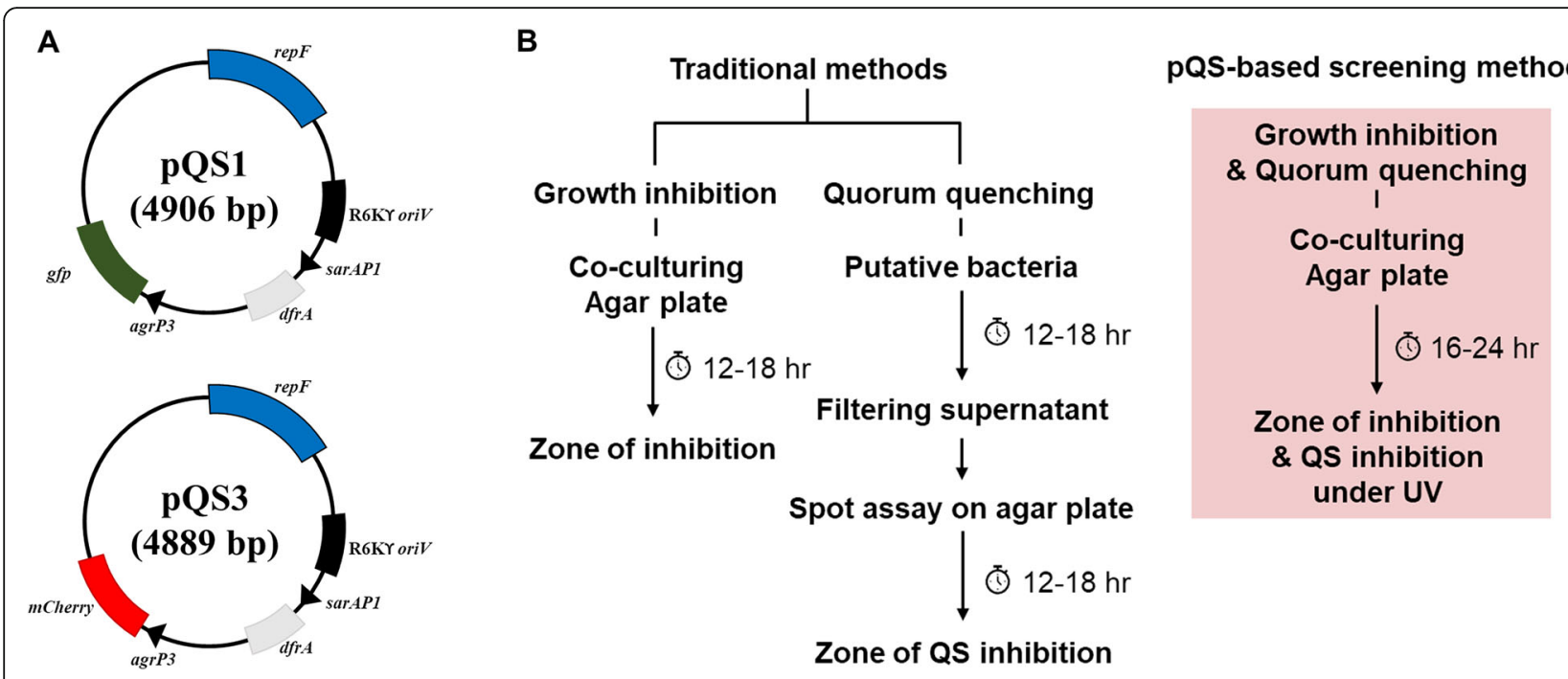

Fig. 1 Diagrams of PQS series and a schematic representation of the PQS-based screening method. A Two newly engineered plasmids contain a trimethoprim-resistant gene (dfrA), two replication origins for E. coli and S. aureus, and a fluorescent gene (gfp $p_{b k}$ or $m$ Cherry) that is controlled by agrP3. B Compared to the traditional methods with two different pipelines, the new pQS-based screening method shows the combined workflow for growth inhibition and QQ and reduces workload and processing time

workflow of this newly proposed method is less demanding and more time efficient compared to traditional methods due to the simultaneous screening (Fig. 1B).

\section{Stability of the PQS Series in S. aureus}

The stability test revealed that both pQS1 and pQS3 were highly stable in four $S$. aureus strains (Sa2, Sa25, Sa27, and Sa30) for at least $24 \mathrm{~h}$ in batch culture conditions without antibiotic selection pressure (Table 1). We also examined the compatibility of $\mathrm{pQS}$ plasmids with a naive pCC97-1 in S. aureus Sa25 by performing plasmid prep and DNA gel electrophoresis. The similarity in band thickness between pQS series and pCC97-1 in wild

Table 1 Stability of pQS series in batch culture

\begin{tabular}{|c|c|c|c|}
\hline \multirow[t]{2}{*}{ Strain and plasmid } & \multicolumn{3}{|c|}{$\%$ of colonies with plasmid } \\
\hline & $\mathrm{Oh}$ & $18 \mathrm{~h}$ & $24 \mathrm{~h}$ \\
\hline \multicolumn{4}{|l|}{ S. aureus Sa2 } \\
\hline pQS1 & $99.97 \pm 0.05$ & $99.88 \pm 0.24$ & $99.64 \pm 0.64$ \\
\hline pQS3 & $100.0 \pm 0.00$ & $99.74 \pm 0.38$ & $98.24 \pm 3.26$ \\
\hline \multicolumn{4}{|l|}{ S. aureus Sa25 } \\
\hline pQS1 & $99.62 \pm 0.22$ & $99.37 \pm 0.55$ & $99.40 \pm 0.46$ \\
\hline pQS3 & $99.65 \pm 0.09$ & $99.30 \pm 0.57$ & $99.13 \pm 0.64$ \\
\hline \multicolumn{4}{|l|}{ S. aureus Sa27 } \\
\hline pQS1 & $99.93 \pm 0.12$ & $99.43 \pm 0.51$ & $99.61 \pm 0.52$ \\
\hline pQS3 & $99.88 \pm 0.15$ & $99.55 \pm 0.93$ & $97.96 \pm 3.48$ \\
\hline \multicolumn{4}{|l|}{ S. aureus Sa30 } \\
\hline pQS1 & $99.63 \pm 0.19$ & $99.42 \pm 0.58$ & $99.41 \pm 0.46$ \\
\hline pQS3 & $99.65 \pm 0.09$ & $99.30 \pm 0.57$ & $99.13 \pm 0.64$ \\
\hline
\end{tabular}

type and transformants supported the co-existence of two different plasmids in S. aureus Sa25 (Additional file 1: Figure S2).

\section{Growth curve and expression of reporter proteins}

To determine if the newly introduced $\mathrm{pQS}$ series influences $S$. aureus growth, the growth rate of four $S$. aureus strains and their transformants was examined. Similar growth rates were observed comparing transformants with the wild-type strains, suggesting no detectable adverse effects of the pQS series on the cells for $48 \mathrm{~h}$ $($ ANOVA $p$-value $=0.43(\mathrm{Sa} 2), 0.51(\mathrm{Sa} 27), 0.80(\mathrm{Sa} 30))$ (Fig. 2A). The Sa25 transformant of pQS1 showed a relatively lower optical density than wild type and other transformants (pKK30 and pQS3) (ANOVA $p$-value $=$ 0.04 ), yet this was not found to be significant during $24 \mathrm{~h}$ of incubation (ANOVA $p$-value $=0.60$ ). The kinetic patterns of reporter proteins in two lineages (CC97 and CC151) were different (Fig. 2B C). The signals from CC151 strains plateaued once the cell reached the stationary phase, while the signals from CC97 strains increased continuously in a linear fashion. The intensity of fluorescent signals from each strain varied. The QS of Sa25 activated $2-5 \mathrm{~h}$ earlier than other strains, resulting in strong signals on agar plates.

\section{Screening antagonistic bacteria against S. aureus}

We confirmed the growth-inhibiting activity of $L$. lactis subsp. lactis ATCC 11454 against S. aureus and variable QQ activities of S. epidermidis ATCC 14990 toward S. aureus Sa25 (Additional file 2: Table S1). From a culture collection containing 81 bacterial isolates from raw milk 


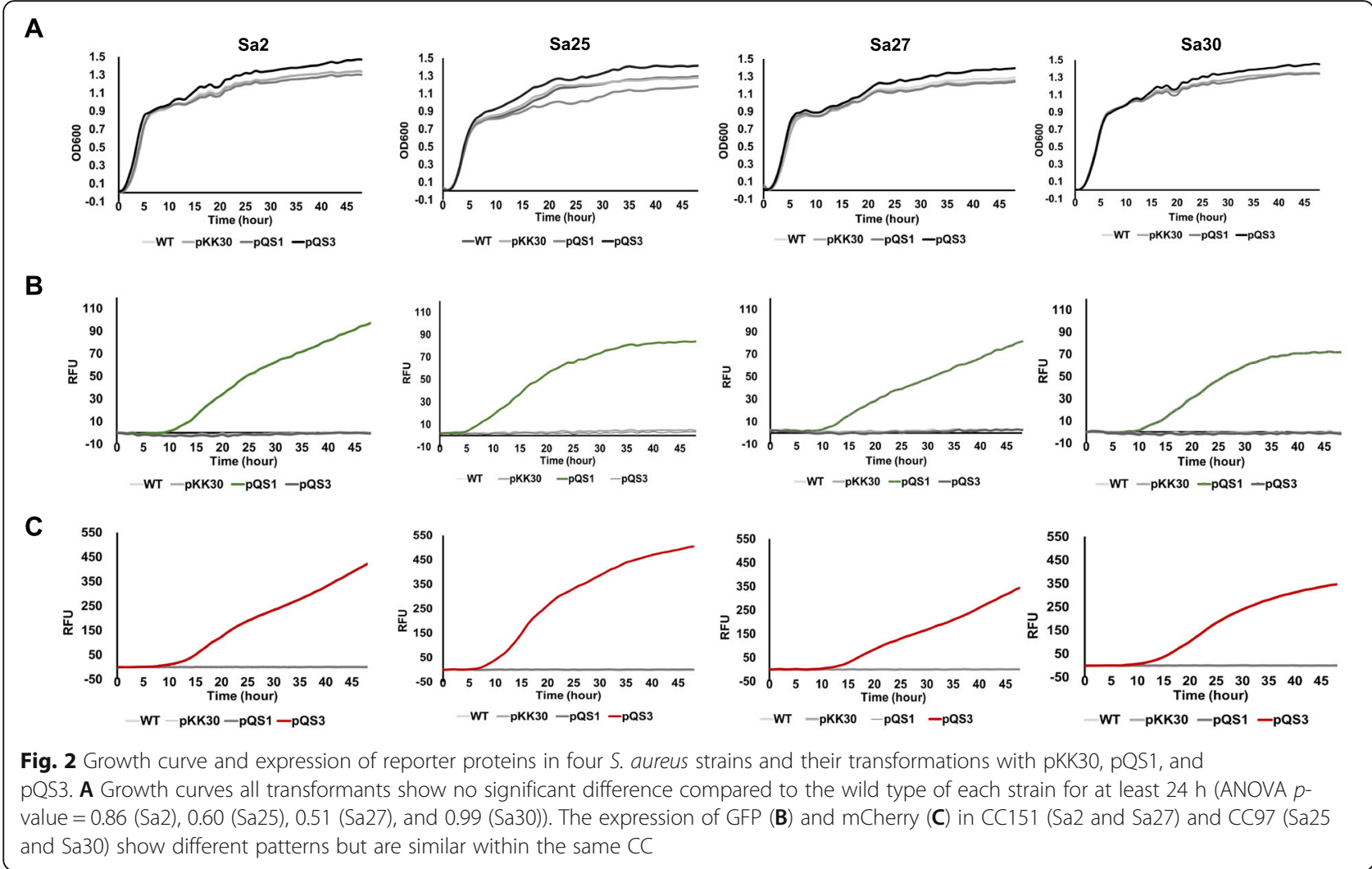

taken from healthy cows, we identified 13 isolates which were able to inhibit the growth of S. aureus, and 13 that have QQ activity toward both Sa25 (CC97) and Sa27 (CC151). All growth-inhibiting bacteria, which were various in phenotypes, were active toward both Sa25 and Sa27 and showed different activities. The growthinhibiting activity of test 32 was similar to those of $L$. lactis subsp. lactis (test 1) and others (test 11, 63, and 65), while some isolates belonging to B. pumilus showed a relatively large zone of growth inhibition. The Sa25 strain had strong QS abilities, and bright fluorescent lawns could be observed after $18 \mathrm{~h}$ of incubation (Fig. 3). The expression of mCherry in plates prepared with pQS3 transformant of Sa25 was visible by the naked eye in white light. We observed the growth inhibition zone around the test bacteria in white light and QQ zone under the UV lamp, which allowed us to screen positive bacteria. Growth-inhibiting bacteria were all Bacillus species except for Aerococcus viridans, and all QQ bacteria belonged to the Staphylococcus genus (Additional file 2: Table S1).

\section{Discussion}

The newly constructed plasmids (pQS series) are retained in transformed $S$. aureus without antibiotic selection pressure in batch conditions for at least $24 \mathrm{~h}$. Taking advantage of this high stability, we developed a new method to screen bacteria for both growthinhibiting and QQ activity towards S. aureus. Ultimately, we were able to identify 13 commensal isolates that were able to inhibit the growth of S. aureus, and a further 13 that exhibited QQ activity. These bacteria were identified previously through $16 \mathrm{~S}$ rRNA gene sequencing and MALDI-TOF. This is a relatively high rate of growthinhibiting activity (13/81) and might be explained by the natural evolution of $S$. aureus and commensal bacteria that have been adapted in the same niche.

At the species level $S$. aureus can cause infection in humans and several species of birds and mammals, however, on a short evolutionary time span certain CCs of $S$. aureus are specialized to single or very few host species $[1,23]$. Bovine mastitis is often a result of $S$. aureus infections, and the $S$. aureus lineages most commonly associated with bovine mastitis are CC8, CC20 CC97, CC151, and C188 [1, 23]. We monitored QS kinetics in two different $S$. aureus lineages commonly associated with clinical bovine mastitis, CC97 and CC151. The isolates Sa25 and Sa30 belong to CC97 and show an exponential up-regulation in the expression of reporter proteins, which is a typical pattern of QS kinetics [24]. Unlike the two CC97 isolates, the two CC151 isolates (Sa2 and Sa27) showed continuous QS activity even after reaching the stationary phase. This kinetic pattern of QS is not a common pattern of QS-regulation [25]. It is 
A
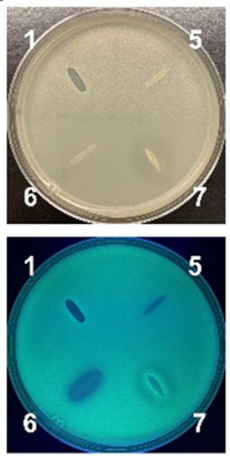

B
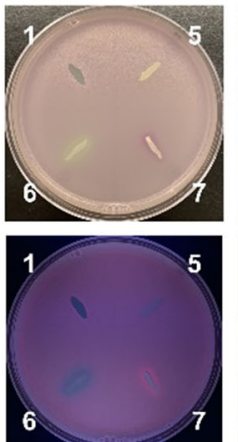
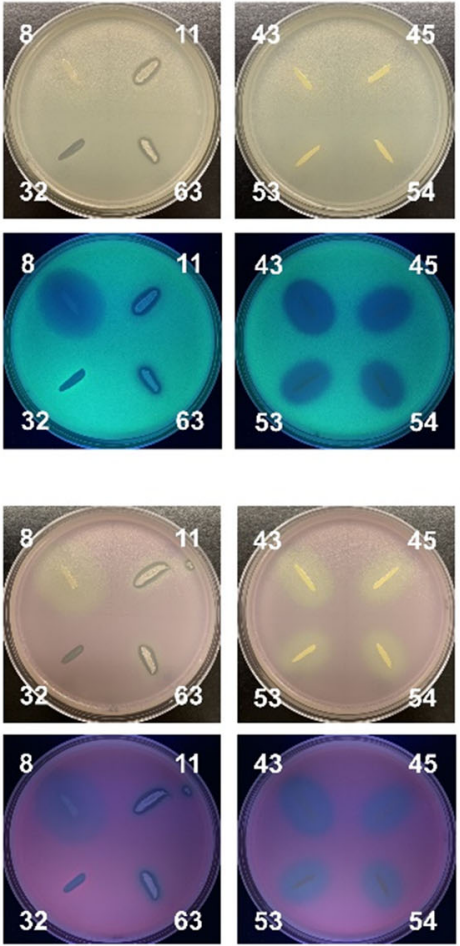
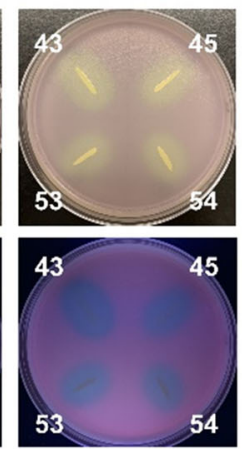
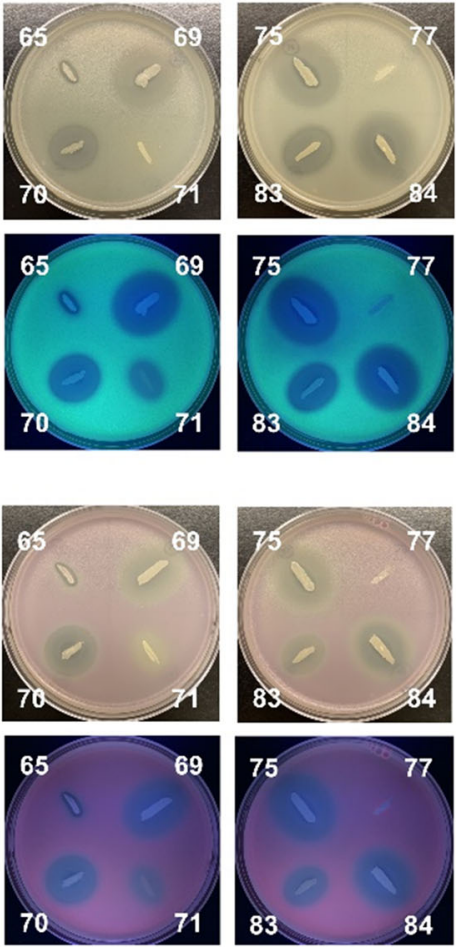

Fig. 3 Screening antagonistic bacteria against S. aureus Sa25 using pQS series. Bacterial lawn prepared with pQS1 (A) and pQS3 (B) transformants of S. aureus Sa25 exhibits the zone of growth inhibition and QQ in the presence of antagonistic bacteria. Plates show glowing fluorescence under UV light (bottom plates of (A) and (B)). Test bacteria streaked on S. aureus Sa25 lawn include L. lactis (test 1), S. aureus Sa25 (test 5), S. aureus Sa27 (test 6), Bacillus pumilus (test 7, 69, 70,75,77, 84), B.altitudinis (test 8), B. subtilis (test 11 and 63), Aerococcus viridans (test 32), S. chromogenes (test 43, 53, and 54), S. saprophyticus (test 45), Bacillus species (test 65), S. pasteuri (test 71), and unknown species (test 83)

unclear if the QS regulation in CC151 provides any selective advantage in bovine intramammary glands, but this could be a possible explanation of this odd pattern of QS-regulation.

Members of the Bacillus genus produce a broad spectrum of non-ribosomally synthesized antimicrobial peptides which have antagonistic activity against pathogenic microbes including $S$. aureus [26]. We observed that B. pumilus inhibited $S$. aureus growth and it was significantly stronger than a known nisin-producer $L$. lactis. B. pumilus and B. subtilis have been known to exhibit anti-Staphylococcus activity by producing various antimicrobial peptides [27-29]. The agr cross-interfering of $S$. aureus mediated by other staphylococci species is the most common as they have similar QS systems and produce peptide analogues $[8,30,31]$. S. epidermidis and $S$. caprae, for example, produce heterologous AIPs and attenuate $S$. aureus virulence by interfering its agr mediated QS $[8,11]$. Interestingly, the QS of Sa25 was more frequently and strongly affected by other Staphylococcus species than Sa27, indicating agr type I may be more vulnerable to the QQ. Another study revealed that cross-talk between $S$. epidermidis and $S$. aureus tends to favour S. epidermidis, and other Staphylococcus species modulate $S$. aureus colonization through the agr crosstalk $[11,19]$. In this study, we observed no QQ activity of S. epidermidis ATCC 14990 toward either AIP-I and AIP-II producers, presumably due to subinhibitory concentration of $\mathrm{AIP}_{\mathrm{ep}} \mathrm{-I}$ in co-culture condition (Additional file 2: Table S1). Although antagonistic bacteria have been suggested as an alternative solution to reduce antibiotics use in dairy farming, intramammary probiotics or intramammary infusion seems to be considered carefully due to the inflammation of mammary glands [32-34]. Indeed, $A$. viridans and non-aureus staphylococci screened in this study are also known clinical and subclinical mastitis pathogens, invalidate their further development as probiotics. However, antagonistic bacteria and their active biomolecules capable of inhibiting $S$. aureus are still promising candidates for therapeutics.

An important aspect of this new screening method is the ability to monitor true interactions between cocultured bacteria. Several studies have reported the cross-inhibition of AIPs produced by S. aureus [10]. A previous study examined the interactions between receptors and cognate AIPs, explaining critical aspects of the 
QS mechanisms in S. aureus [35]. Previous studies used different $S$. aureus strains with different agr systems to examine the interference of $S$. aureus QS mediated by non-cognate AIP in culture supernatant or purified noncognate AIP of another $S$. aureus strain [36, 37]. However, these conditions cause bias towards the noncognate AIP producer due to counter inhibition being omitted from the assays. In this study, we observed no QQ activity of Sa25 (agr type I) toward Sa27 (agr type II) in co-culture conditions, whereas Sa27 inhibited the QS of Sa25. This result suggests that AIP-dependent cross-inhibition might not reflect the natural QS interferences when $S$. aureus strains with different agr systems co-colonize and interact bi-directionally in the same niche. A superior agr type over another might exist between $S$. aureus during co-colonization resulting from the timing of QS activation and strength. More importantly, antagonistic molecules produced by bacteria are not primary metabolites, so without survival advantages under certain conditions, bacteria rarely accumulate these compounds enough to kill or interrupt others. Many studies have supported the idea that interspecies interactions stimulate bacterial metabolism and induce the expression of silence genes [38-41]. This metabolic response in bacteria should be considered in the development of antibacterial therapy and probiotic drugs.

A limitation of this new pQS series mainly stems from the possibility of losing $\mathrm{pQS}$ plasmids from $S$. aureus host cells leading to false positives. The stationary phase during co-culture can affect the plasmid stability due to fitness costs in unfavourable conditions such as nutrient exhaustion, accumulated inhibitory metabolites, and lack of physical space. Antagonistic compounds produced by co-cultured bacteria increase fitness cost affecting plasmid stability in $S$. aureus. Despite this limitation, pQS plasmids can broaden the range of target $S$. aureus strains in screening antagonistic bacteria in the simplest way. The fluorescent reporter genes in the pQS plasmids can be readily replaced by other reporter genes such as lac $Z$, providing flexibilities in detection. Although the pQS series favours qualitative assay, quantitative assay in QS of $S$. aureus is feasible in co-culture conditions. The pQS plasmids are applicable to other research fields in $S$. aureus studies such as image dynamics and bio-sensors specific for $S$. aureus QS.

\section{Conclusions}

We demonstrated the high stability of the newly constructed $\mathrm{pQS}$ plasmids without antibiotic selection pressure. Taking advantage of the highly stable plasmids and the QS-dependent expression of reporter proteins, we were able to co-culture $S$. aureus with other bacteria and examine $S$. aureus growth and QS simultaneously on agar media. Our results demonstrate that this high- throughput screening strategy significantly reduces workload and processing time in finding antagonistic bacteria against $S$. aureus. Newly found antagonistic bacteria and their bioactive compounds can be used to develop promising probiotic drugs and prophylactics/ therapeutics capable of preventing and treating S. aureus infections.

\section{Methods}

Bacterial strains, plasmids, and media

Escherichia coli DH5 $\alpha \lambda$ pir (NR-50,350, BEI resources) served as the host for plasmid constructions and grew in lysogeny broth (LB) medium supplemented with ampicillin $(100 \mu \mathrm{g} / \mathrm{mL})$ (Sigma-Aldrich) or tryptic soy broth (TSB) medium with trimethoprim $(10 \mu \mathrm{g} / \mathrm{mL})$ (SigmaAldrich). S. aureus strains were cultured in TSB with or without trimethoprim $(10 \mu \mathrm{g} / \mathrm{mL})$. All engineered plasmids in $E$. coli $\mathrm{DH} 5 \alpha \lambda$ pir were transferred into $S$. aureus RN4220 (BEI resources, NR-45,946) as an intermediate strain, and then introduced to other $S$. aureus isolates, which were collected from Holstein dairy milk (Table 2). This study used various bacterial strains, plasmids, and oligonucleotides (Table 2). We purchased Lactococcus lactis subsp. Lactis (ATCC 11454) and S. epidermis (ATCC 14990) from the American Type Culture Collection (Manassas, VA, USA) and obtained non-aureus Staphylococci strains $(n=17)$ isolated from dairy cows from the mastitis pathogens culture collection (Additional file 2: Table S1) [42]. A total of 64 bacterial isolates from raw milk taken from animals with no signs of clinical mastitis was obtained from the Macdonald Campus Farm, McGill University, Ste-Anne-de-Bellevue, Quebec were used for the antagonistic test (Additional file 2: Table S1).

\section{Molecular genetic techniques}

Restriction enzymes and T4 DNA ligase were purchased from New England BioLabs (NEB). Hot Start Taq Master Mix was purchased from Qiagen (Hilden, Germany), and PCR was performed with a Veriti ${ }^{\text {ix }}$ 96-Well Thermal Cycler (Applied Biosystems). Oligonucleotides, including primers and agrP3-mCherry, were synthesized by IDT DNA Technologies (Coralville, IA). The sequence of codon-optimized mCherry was obtained from NCBI under accession number LC088724 [48]. All amplicons and digested DNA were purified using Monarch ${ }^{\circ}$ PCR \& DNA Cleanup Kit (NEB). Plasmid DNA was purified using Monarch $^{\circ}$ Plasmid Miniprep Kit (NEB) after pretreatment of $S$. aureus cells with $20 \mu \mathrm{g}$ of lysostaphin (Sigma-Aldrich) for $30 \mathrm{~min}$ at $37^{\circ} \mathrm{C}$.

\section{Construction of QS reporter vectors}

From the genomic DNA of S. aureus 31210331, the QS promoter (agrP3) was amplified by PCR using the 
Table 2 Bacterial strains, plasmids, and oligonucleotides

\begin{tabular}{|c|c|c|}
\hline Bacteria, plasmid, oligonucleotides & Relevant characteristic(s) or sequence & Source \\
\hline \multicolumn{3}{|l|}{ Bacterial strains } \\
\hline E. coli DH5a入pir & Plasmid cloning strain & [21] \\
\hline S. aureus RN4220 & Restriction deficient strain, partially defective AgrA & [43] \\
\hline S. aureus 10400326 or Sa2 & ST351, AIP-II producer & [44] \\
\hline S. aureus 10303344 or Sa25 & ST352, AIP-I producer & [44] \\
\hline S. aureus 41000044 or Sa27 & ST151, AIP-II producer & [44] \\
\hline S. aureus 21000024 or Sa30 & ST352, AIP-I producer & [44] \\
\hline L. lactis subsp. lactis ATCC 11454 & Nisin producer & [45] \\
\hline S. epidermidis ATCC 14990 & AIP $_{\mathrm{ep}}-1$ producer & [46] \\
\hline \multicolumn{3}{|l|}{ Plasmids } \\
\hline pBGR1 & Promoter trap vector & [47] \\
\hline pKK30 & Highly stable plasmid containing $P_{\text {sarAP1 }}-d f r A$ & [21] \\
\hline pQS1 & pKK30 containing $P_{a g r P 3}-g f p_{b k}$ & This study \\
\hline pQS3 & pKK30 containing $\mathrm{P}_{\text {agr }}$ 3-mCherry & This study \\
\hline \multicolumn{3}{|l|}{ Primers } \\
\hline AGRP3-F3 (ECORI) & AAAGAATTCGTAATTTGTATTTAATATTTTAAC & This study \\
\hline AGRP3-F4 (Nhel) & AAAGCTAGCGTAATTTGTATTTAATATTTAAC & This study \\
\hline AGRP3-R1 (BamHI) & AAAGGATCCCAACTATTTTCCATCAC & This study \\
\hline GFP-R1 (EcoRV) & AAAGATATCTTATTTGTAGAGCTC & This study \\
\hline mCherry-R1 (BamHI) & AAAGGATCCCTACTTGTACAGCTC & This study \\
\hline
\end{tabular}

AGRP3-F3 and AGRP3-R1 primers (Table 2). The agrP3 amplicons and pBGR1 plasmid, containing bidirectional reporter genes ( $d s R e d$ and $\left.g f p_{b k}\right)$, were digested with EcoRI and BamHI and then ligated together to create pBGR1-agrP3. Next, the agrP3-gfp $b k$ module from pBGR1-agrP3 was amplified using the AGRP3-F4 and GFP-R1 primers (Table 2) and then digested with NheI and EcoRV. The plasmid pKK30 was digested with NheI and SmaI and ligated together with the digested agrP3$g f p_{b k}$ amplicon to generate pQS1. The synthetic module agrP3-mCherry from pBGR1-agrP3 was amplified using AGRP3-F4 and mCherry-R2 (Table 2). The agrP3$m$ Cherry amplicons and pKK30 were digested with NheI and $B a m \mathrm{HI}$ and then ligated together to create pQS3.

Heat-shock was used to transform recombinant into calcium competent E. coli DH $5 \alpha \lambda$ pir. Electrocompetent $S$. aureus cells were prepared as described previously with minor modifications [49]. Approximately $0.1 \mu \mathrm{g}$ of plasmid DNA and $70 \mu \mathrm{L}$ of electrocompetent $S$. aureus cells were combined and then pulsed at $2.3 \mathrm{kV}, 100 \Omega$, and $25 \mu \mathrm{F}$ in $0.1 \mathrm{~cm}$ cuvette using the Gene Pulser Electroporation System (BioRad Laboratories). The pulsed cells were transferred into $1 \mathrm{~mL}$ of BHI broth and incubated for $1 \mathrm{~h}$ at 37 ${ }^{\circ} \mathrm{C}$ at $200 \mathrm{rpm}$. The cell suspensions were grown on TSA with trimethoprim $(10 \mu \mathrm{g} / \mathrm{mL})$ and incubated overnight at $37{ }^{\circ} \mathrm{C}$. Only transformants harbouring either pQS1 or pQS3 were recovered.

\section{Cell culture and evaluation of $\mathrm{pQS}$ series}

We prepared bacterial cultures by inoculating a single colony in $5 \mathrm{~mL}$ of TSB with trimethoprim $(10 \mu \mathrm{g} / \mathrm{mL})$ and incubated at $37{ }^{\circ} \mathrm{C}$ at $200 \mathrm{rpm}$ up to an $\mathrm{OD}_{600}$ of 1.5-2.0. Next, $1 \mathrm{~mL}$ of the culture broth was centrifuged; the supernatant was removed, and then the pellet was resuspended by adding $0.5 \mathrm{~mL}$ of TSB. The density of the cell cultures was determined, and the resuspensions were diluted up to an $\mathrm{OD}_{600}$ of 0.01 in the required volume of TSB. Next a series of tests to assess plasmid stability, plasmid compatibility, cell growth, and the expression of reporter proteins were performed to evaluate $\mathrm{pQS}$ plasmids.

To assess the stability of the pQS series in four S. aureus strains, a batch culture test was performed from the early exponential phase to the stationary phase. Briefly, the resuspended cells were diluted to an $\mathrm{OD}_{600}$ of 0.01 in $20 \mathrm{~mL}$ of TSB $(0 \mathrm{~h})$, and then incubated in three independent $5 \mathrm{~mL}$ aliquots at $37{ }^{\circ} \mathrm{C}$ at $200 \mathrm{rpm}$. Immediately after the first inoculation a sample was collected, diluted to $10^{-3}$, and $0.1 \mathrm{~mL}$ of the $10^{-3}$ dilution was spread on TSA. TSA plates were incubated for $24 \mathrm{~h}$ at $37{ }^{\circ} \mathrm{C}$. At 18 and $24 \mathrm{~h}$ of incubation, $0.5 \mathrm{~mL}$ sample of each culture 
was serially diluted to $10^{-6}$, and $0.1 \mathrm{~mL}$ of the final dilution was spread on TSA plates. After 24-hour incubation, plates were observed under a UV lamp, and the total number of colonies and the number of nonfluorescent colonies were counted.

To examine plasmid compatibility, we performed a rapid method previously described [50]. From the initial culture cells of $S$. aureus Sa25 and its transformants, we diluted the resuspended cells up to an $\mathrm{OD}_{600}$ of 0.01 in $5 \mathrm{~mL}$ of TSB either with or without trimethoprim $(10 \mu \mathrm{g} / \mathrm{mL})$. After incubation at $37{ }^{\circ} \mathrm{C}$ up to an $\mathrm{OD}_{600}$ of 1.5 , plasmid DNA was extracted using $3 \mathrm{~mL}$ of culture cells from each test tubes. The thickness of plasmid bands was compared on a DNA agarose gel after gel electrophoresis.

The resuspended cells were diluted to an $\mathrm{OD}_{600}$ of 0.01 in $1 \mathrm{~mL}$ of TSB to monitor the growth rate and the expression of GFP and mCherry. From this dilution, 0.2 $\mathrm{mL}$ of diluted cells were transferred into a black 96-well plate in triplicate. The plate was incubated in Synergy HTX (BioTek) for $48 \mathrm{~h}$ at $37{ }^{\circ} \mathrm{C}, 205 \mathrm{cpm}(5 \mathrm{~mm})$ in continuous shaking mode, and the $\mathrm{OD}_{600}$ and relative fluorescence units (RFU) of GFP and mCherry were measured every hour. GFP was excited at $485 \mathrm{~nm}$, and the emission was detected at $528 \mathrm{~nm}$. mCherry was excited at $575 \mathrm{~nm}$, and the emission was detected at 620 nm.

\section{Antagonistic activity test}

Testing for antagonistic activity between commensal isolates from milk and S. aureus were carried out on TSA, S. aureus transformants containing either $\mathrm{pQS1}$ or $\mathrm{pQS3}$ were used to make a bacterial lawn. The pre-culture of transformants was prepared as described above. S. aureus cells resuspended to an $\mathrm{OD}_{600}$ of 0.01 in $25 \mathrm{~mL}$ of soft TSA media at approximately $45{ }^{\circ} \mathrm{C}$ and placed in a petri dish. After the agar solidified, the commensal bacteria isolated from dairy milk were streaked on the plates and then incubated for $16-24 \mathrm{~h}$ at $37{ }^{\circ} \mathrm{C}$. The growth inhibition and the QQ zone were observed under white light and UV light, respectively.

\section{Statistical analysis}

The results were subjected to one-way analysis of variance at a significance level of $p<0.05$, to compare tested samples. The average of each triplicate was used for the statistical analysis.

\section{Abbreviations}

ABR: Antibiotic resistance; QS: Quorum-sensing; QQ: Quorum-quenching; agr: Accessory gene regulator; AIP: Autoinducing peptides; CC: Clonal complex

\section{Supplementary Information}

The online version contains supplementary material available at https://doi. org/10.1186/s12866-021-02265-4.

Additional file 1: Figure S1. Expression of the reporter protein in agr defective strain (RN4220) and positive strain (Sa25). Two plasmids pQS1 and pQS3 were transformed to S. aureus RN4220 (agr-) and Sa25. After $24 \mathrm{~h}$ of incubation either with or without trimethoprim, no fluorescent colony was observed from the transformants of S. aureus RN4220, while the transformants of S. aureus Sa25 exhibited clear fluorescent phenotypes. Figure S2. Agarose gel electrophoresis of plasmid DNA. The first lane contains a single DNA band of pCC97-1. Other lands contain two DNA bands corresponding to pCC97-1 and pQS plasmids, indicating the co-existence of two plasmids in the same $S$. aureus cells.

Additional file 2: Table S1. Bacteria used in screening antagonistic bacteria using the pQS-based methods and their growth-inhibiting (Gl) and quorum-quenching (QQ) activity toward S. aureus.

\section{Acknowledgements}

We want to thank BEl resources for providing the following reagents: $E$. coli DH5aגpir (NR-50350), S. aureus RN4220 (NR-45946), and pKK30 in E. coli DH5aגpir (NR-50349). We also thank the Macdonald Campus farm for providing raw milk from which to obtain novel bacterial isolates.

\section{Authors' contributions}

SP designed the study, wrote the manuscript, and performed experimentation. JR and GK provided critical expertise for the experimental design and the manuscript. HG and RM participated in the plasmid stability test and AC participated in the antagonistic activity test. EK and CD isolated commensal bacteria from dairy milk. All authors read and approved the final manuscript.

\section{Funding}

This research received financial support from the McGill Sustainability Systems Initiative (MSSI) through the Ideas Fund awarded to SP, as well as a Dairy Farmers of Canada Research Cluster III grant awarded to JR. SP is grateful for receiving scholarships from the NSERC CREATE in Milk Quality (Université de Montréal, St-Hyacinthe, QC, Canada) and from Op + lait, the FRQNT Regroupement stratégique pour un lait de qualité optimale (Université de Montréal, St-Hyacinthe, QC, Canada).

\section{Availability of data and materials}

The sequences of pQS1 (accession number MW344079) and pQS3 (accession number MW344080) are available in GenBank at the NCBI (GenBank, https:// www.ncbi.n/m.nih.gov/genbank/). The datasets used and analyzed during the current study are available from the corresponding author on reasonable request.

\section{Declarations}

Ethics approval and consent to participate Not applicable.

Consent for publication

Not applicable.

\section{Competing interests}

Dr. Jennifer Ronholm is a Senior Editorial Board Member of BMC Microbiology.

\section{Author details}

${ }^{1}$ Department of Food Science and Agricultural Chemistry, Faculty of Agricultural and Environmental Sciences, McGill University, Macdonald Campus, 21,111 Lakeshore Ste Anne de Bellevue, QC H9X 3V9 Montreal, Canada. ${ }^{2}$ Department of Biological Sciences, College of Natural Science, Chonnam National University, Yong-Bong Dong, Buk-Gu, 500-757 Gwangju, Korea. ${ }^{3}$ Department of Animal Science, Faculty of Agricultural and Environmental Sciences, McGill University, Macdonald Campus, 21,111 Lakeshore, Ste-Anne-de-Bellevue, QC H9X 3V9, Canada. 
Received: 23 March 2021 Accepted: 10 June 2021

Published online: 24 June 2021

\section{References}

1. Park S, Ronholm J. Staphylococcus aureus in Agriculture: Lessons in Evolution from a Multispecies Pathogen. Clin Microbiol Rev. 2021;34(2). https://doi.org/10.1128/CMR.00182-20.

2. Balasubramanian D, Harper L, Shopsin B, Torres VJ. Staphylococcus aureus pathogenesis in diverse host environments. Pathog Dis. 2017;75(1). https:// doi.org/10.1093/femspd/ftx005.

3. Karska-Wysocki B, Bazo M, Smoragiewicz W. Antibacterial activity of Lactobacillus acidophilus and Lactobacillus casei against methicillin-resistant Staphylococcus aureus (MRSA). Microbiol Res. 2010;165(8):674-86. https:// doi.org/10.1016/j.micres.2009.11.008.

4. Sikorska $\mathrm{H}$, Smoragiewicz W. Role of probiotics in the prevention and treatment of meticillin-resistant Staphylococcus aureus infections. Int J Antimicrob Agents. 2013;42(6):475-81. https://doi.org/10.1016/j.jjantimicag.2 013.08.003.

5. Piewngam $P$, Zheng $Y$, Nguyen $T H$, Dickey $S W$, Joo $H$-S, Villaruz $A E$, et al. Pathogen elimination by probiotic Bacillus via signalling interference. Nature. 2018;562(7728):532-7. https://doi.org/10.1038/s41586-018-0616-y.

6. York A. Silencing Staphylococcus aureus with probiotics. Nat Rev Microbiol. 2018;16(12):715. https://doi.org/10.1038/s41579-018-0111-3.

7. Piewngam P, Otto M. Probiotics to prevent Staphylococcus aureus disease? Gut Microbes. 2020;11(1):94-101. https://doi.org/10.1080/19490976.2019.1 591137.

8. Paharik AE, Parlet CP, Chung N, Todd DA, Rodriguez El, Van Dyke MJ, et al. Coagulase-Negative Staphylococcal Strain Prevents Staphylococcus aureus Colonization and Skin Infection by Blocking Quorum Sensing. Cell Host Microbe. 2017;22(6):746-56. https://doi.org/10.1016/j.chom.2017.11.001 e5.

9. Scoffone VC, Trespidi G, Chiarelli LR, Barbieri G, Buroni S. Quorum Sensing as Antivirulence Target in Cystic Fibrosis Pathogens. Int J Mol Sci. 2019;20(8)3. https://doi.org/10.3390/ijms20081838.

10. Wang B, Muir TW. Regulation of Virulence in Staphylococcus aureus: Molecular Mechanisms and Remaining Puzzles. Cell Chem Biol. 2016;23(2): 214-24. https://doi.org/10.1016/j.chembiol.2016.01.004.

11. Otto M, Echner H, Voelter W, Gotz F. Pheromone cross-inhibition between Staphylococcus aureus and Staphylococcus epidermidis. Infect Immun. 2001;69(3):1957-60. https://doi.org/10.1128/IAl.69.3.1957-1960.2001.

12. Mansson M, Nielsen A, Kjaerulff L, Gotfredsen $\mathrm{CH}$, Wietz $M$, Ingmer $H$, et al. Inhibition of virulence gene expression in Staphylococcus aureus by novel depsipeptides from a marine photobacterium. Mar Drugs. 2011;9(12):253752. https://doi.org/10.3390/md9122537.

13. Qazi S, Middleton B, Muharram SH, Cockayne A, Hill P, O'Shea P, et al. Nacylhomoserine lactones antagonize virulence gene expression and quorum sensing in Staphylococcus aureus. Infect Immun. 2006;74(2):910-9. https:// doi.org/10.1128/iai.74.2.910-919.2006.

14. Gordon CP, Williams P, Chan WC. Attenuating Staphylococcus aureus virulence gene regulation: a medicinal chemistry perspective. J Med Chem. 2013;56(4):1389-404. https://doi.org/10.1021/jm3014635.

15. Grunenwald CM, Bennett MR, Skaar EP. Nonconventional Therapeutics against Staphylococcus aureus. Microbiology Spect. 2018;6(6):https://doi. org/10.1128/microbiolspec.GPP3-0047-2018.

16. Liu W, Chen M, Duo L, Wang J, Guo S, Sun H, et al. Characterization of potentially probiotic lactic acid bacteria and bifidobacteria isolated from human colostrum. J Dairy Sci. 2020;103(5):4013-25. https://doi.org/10.3168/ jds.2019-17602.

17. Huidrom S, Sharma N. Isolation and screening of novel isolates of Bifidobacteria from human milk as potential probiotic with antidiarrheal activity. Ann Appl Microbiol Biotechnol J. 2018;2(1):1007-15.

18. Acai P, Medved'ova A, Mancuskova T, Valik L. Growth prediction of two bacterial populations in co-culture with lactic acid bacteria. Food Sci Technol Int. 2019;25(8):692-700. https://doi.org/10.1177/1082013219860360.

19. Peng P, Baldry M, Gless BH, Bojer MS, Espinosa-Gongora C, Baig SJ, et al. Effect of Co-inhabiting Coagulase Negative Staphylococci on S. aureus agr Quorum Sensing, Host Factor Binding, and Biofilm Formation. Front Microbiol. 2019;10:2212. https://doi.org/10.3389/fmicb.2019.02212.

20. Urbano R, Karlinsey JE, Libby SJ, Doulias PT, Ischiropoulos H, Warheit-Niemi $\mathrm{HI}$, et al. Host Nitric Oxide Disrupts Microbial Cell-to-Cell Communication to Inhibit Staphylococcal Virulence. Cell Host Microbe. 2018;23(5):594-606. https://doi.org/10.1016/j.chom.2018.04.001 e7.
21. Krute CN, Krausz KL, Markiewicz MA, Joyner JA, Pokhrel S, Hall PR, et al. Generation of a Stable Plasmid for In Vitro and In Vivo Studies of Staphylococcus Species. Appl Environ Microbiol. 2016;82(23):6859-69. https://doi.org/10.1128/AEM.02370-16.

22. Rodriguez MD, Paul Z, Wood CE, Rice KC, Triplett EW. Construction of Stable Fluorescent Reporter Plasmids for Use in Staphylococcus aureus. Front Microbiol. 2017:8:2491. https://doi.org/10.3389/fmicb.2017.02491.

23. Matuszewska M, Murray GGR, Harrison EM, Holmes MA, Weinert LA. The Evolutionary Genomics of Host Specificity in Staphylococcus aureus. Trends Microbiol. 2020;28(6):465-77. https://doi.org/10.1016/j.tim.2019.12.007.

24. Novick RP, Geisinger E. Quorum sensing in staphylococci. Annu Rev Genet. 2008:42:541-64. https://doi.org/10.1146/annurev.genet.42.110807.091640.

25. Podbielski A, Kreikemeyer B. Cell density-dependent regulation: basic principles and effects on the virulence of Gram-positive cocci. Int J Infect Dis. 2004;8(2):81-95. https://doi.org/10.1016/j.jij.2003.04.003.

26. Sumi CD, Yang BW, Yeo IC, Hahm YT. Antimicrobial peptides of the genus Bacillus: a new era for antibiotics. Can J Microbiol. 2015;61(2):93-103. https://doi.org/10.1139/cjm-2014-0613.

27. Terekhov SS, Nazarov AS, Mokrushina YA, Baranova MN, Potapova NA, Malakhova MV, et al. Deep Functional Profiling Facilitates the Evaluation of the Antibacterial Potential of the Antibiotic Amicoumacin. Antibiotics (Basel). 2020;9(4). https://doi.org/10.3390/antibiotics9040157.

28. Zidour M, Belquesmia Y, Cudennec B, Grard T, Flahaut C, Souissi S, et al. Genome Sequencing and Analysis of Bacillus pumilus ICVB403 Isolated from Acartia tonsa Copepod Eggs Revealed Surfactin and Bacteriocin Production: Insights on Anti-Staphylococcus Activity. Probiotics Antimicrob Proteins. 2019;11(3):990-8. https://doi.org/10.1007/s12602-018-9461-4.

29. Wu S, Jia S, Sun D, Chen M, Chen X, Zhong J, et al. Purification and characterization of two novel antimicrobial peptides Subpeptin JM4-A and Subpeptin JM4-B produced by Bacillus subtilis JM4. Curr Microbiol. 2005; 51(5):292-6. https://doi.org/10.1007/s00284-005-0004-3.

30. Canovas J, Baldry M, Bojer MS, Andersen PS, Grzeskowiak PK, Stegger M, et al. Cross-Talk between Staphylococcus aureus and Other Staphylococcal Species via the agr Quorum Sensing System. Front Microbiol. 2016;7:1733. https://doi.org/10.3389/fmicb.2016.01733.

31. Mahmmod YS, Klaas IC, Svennesen L, Pedersen $K$, Ingmer $H$. Communications of Staphylococcus aureus and non-aureus Staphylococcus species from bovine intramammary infections and teat apex colonization. J Dairy Sci. 2018;101(8):7322-33. https://doi.org/10.31 68/jds.2017-14311.

32. Rainard P, Foucras G. A Critical Appraisal of Probiotics for Mastitis Control. Front Vet Sci. 2018;5:251. https://doi.org/10.3389/fvets.2018.00251.

33. Klostermann K, Crispie F, Flynn J, Ross RP, Hill C, Meaney W. Intramammary infusion of a live culture of Lactococcus lactis for treatment of bovine mastitis: comparison with antibiotic treatment in field trials. J Dairy Res. 2008;75(3):365-73. https://doi.org/10.1017/S0022029908003373.

34. Mignacca SA, Dore S, Spuria L, Zanghi P, Amato B, Dupre I, et al. Intramammary infusion of a live culture of Lactococcus lactis in ewes to treat staphylococcal mastitis. J Med Microbiol. 2017;66(12):1798-810. https:// doi.org/10.1099/jmm.0.000641.

35. Lyon GJ, Wright JS, Muir TW, Novick RP. Key determinants of receptor activation in the agr autoinducing peptides of Staphylococcus aureus. Biochemistry. 2002;41(31):10095-104. https://doi.org/10.1021/bi026049u.

36. Ji G, Beavis R, Novick RP. Bacterial interference caused by autoinducing peptide variants. Science. 1997;276(5321):2027-30. https://doi.org/10.1126/ science.276.5321.2027.

37. Jarraud S, Lyon GJ, Figueiredo AM, Lina G, Vandenesch F, Etienne J, et al. Exfoliatin-producing strains define a fourth agr specificity group in Staphylococcus aureus. J Bacteriol. 2000;182(22):6517-22. https://doi.org/1 0.1128/jb.182.22.6517-6522.2000.

38. Traxler MF, Watrous JD, Alexandrov T, Dorrestein PC, Kolter R. Interspecies interactions stimulate diversification of the Streptomyces coelicolor secreted metabolome. mBio. 2013;4(4). https://doi.org/10.112 8/mBio.00459-13.

39. Moody SC. Microbial co-culture: harnessing intermicrobial signaling for the production of novel antimicrobials. Future Microbiol. 2014;9(5):575-8. https://doi.org/10.2217/fmb.14.25.

40. Netzker T, Fischer J, Weber J, Mattern DJ, Konig CC, Valiante V, et al. Microbial communication leading to the activation of silent fungal secondary metabolite gene clusters. Front Microbiol. 2015;6:299. https://doi. org/10.3389/fmicb.2015.00299. 
41. Bertrand S, Bohni N, Schnee S, Schumpp O, Gindro K, Wolfender JL. Metabolite induction via microorganism co-culture: a potential way to enhance chemical diversity for drug discovery. Biotechnol Adv. 2014;32(6): 1180-204. https://doi.org/10.1016/i.biotechadv.2014.03.001.

42. Dufour S, Labrie J, Jacques M. The Mastitis Pathogens Culture Collection. Microbiol Resour Announc. 2019;8(15). https://doi.org/10.1128/MRA.00133-1 9.

43. Nair D, Memmi G, Hernandez D, Bard J, Beaume M, Gill S, et al. Wholegenome sequencing of Staphylococcus aureus strain RN4220, a key laboratory strain used in virulence research, identifies mutations that affect not only virulence factors but also the fitness of the strain. J Bacteriol. 2011; 193(9):2332-5. https://doi.org/10.1128/JB.00027-11.

44. Park S, Jung D, Dufour S, Ronholm J. Draft Genome Sequences of 27 Staphylococcus aureus Strains and 3 Staphylococcus Species Strains Isolated from Bovine Intramammary Infections. Microbiol Resour Announc. 2020; 9(19). https://doi.org/10.1128/MRA.00300-20.

45. Millette M, Smoragiewicz W, Lacroix M. Antimicrobial potential of immobilized Lactococcus lactis subsp. lactis ATCC 11454 against selected bacteria. J Food Prot. 2004;67(6):1184-9. https://doi.org/10.4315/0362-028x67.6.1184.

46. Otto M, Sussmuth R, Jung G, Gotz F. Structure of the pheromone peptide of the Staphylococcus epidermidis agr system. FEBS Lett. 1998;424(1-2):89-94. https://doi.org/10.1016/s0014-5793(98)00145-8.

47. Han SS, Lee JY, Kim WH, Shin HJ, Kim GJ. Screening of promoters from metagenomic DNA and their use for the construction of expression vectors. J Microbiol Biotechnol. 2008;18(10):1634-40

48. Kato F, Nakamura M, Sugai M. The development of fluorescent protein tracing vectors for multicolor imaging of clinically isolated Staphylococcus aureus. Sci Rep. 2017;7(1):2865. https://doi.org/10.1038/s41598-017-02930-7.

49. Grosser MR, Richardson AR. Method for Preparation and Electroporation of S. aureus and S. epidermidis. Methods Mol Biol. 2016;1373:51-7. https://doi. org/10.1007/7651_2014_183.

50. Palomares JC, Perea EJ. A rapid method of determining the incompatibility group of R plasmid. Plasmid. 1980;4(3):352-3. https://doi.org/10.1016/0147619x(80)90073-6.

\section{Publisher's Note}

Springer Nature remains neutral with regard to jurisdictional claims in published maps and institutional affiliations.

Ready to submit your research? Choose BMC and benefit from:

- fast, convenient online submission

- thorough peer review by experienced researchers in your field

- rapid publication on acceptance

- support for research data, including large and complex data types

- gold Open Access which fosters wider collaboration and increased citations

- maximum visibility for your research: over $100 \mathrm{M}$ website views per year

At $\mathrm{BMC}$, research is always in progress.

Learn more biomedcentral.com/submissions 